https://doi.org/10.52058/2786-4952-2021-2(2)-235-244

Лукомська Світлана Олексіївна кандидат психологічних наук, старший науковий співробітник лабораторії методології і теорії психології, Інститут психології імені Г.С. Костюка НАПН України, вул. Паньківська, 2, м. Київ, 01033, тел.: (067) 836-08-24, e-mail: svitluk@ukr.net, https://orcid.org/0000-00020360-6484

\title{
ЖИТТСВI НАРАТИВИ ПЕРСОНАЖІВ РОМАНУ Г. POУ «LA ROUTE D'ALTAMONT» TA МУЗИЧНОГО АЛЬБОМУ «LE VIEILLARD ET L'ENFANT», СТВОРЕНОГО НА ЙОГО ОСНОВІ
}

Анотація. У статті проаналізовано особливості життєвих наративів персонажів роману канадійської письменниці Г. Роу «Дорога до Альтамонту», зокрема другої його частини «Старий і дитина» та однойменного музичного альбому, створеного у 2021 році за його мотивами. Габріель Роу (1909-1983) відома канадська письменниця, громадський діяч, одна з головних фігур у французькій канадській літературі. Написані простим і лаконічним стилем, твори Г. Роу сьогодні цікавлять широку публіку, як в Канаді, так і за їі межами. Роман «La route d'Altamont» («Дорога до Альтамонту», 1966) присвячений висвітленню автобіографічного наративу та особистісної ідентичності людей різного віку, екзистенційним проблемам, що актуалізуються у кризових життєвих ситуаціях. «La Route d'Altamont» попри те, що містить чотири незалежні тексти, кожен 3 яких розповідає закінчену історію, не є збіркою оповідань, а - романом-сагою, жанром, який одночасно фрагментований і уніфікований, має гнучку структуру, яка базується на концепції життєвого шляху людини. Концепт особистісної ідентичності у тексті актуалізується насамперед в тому, що розповідь ведеться від імені Крістін, яка водночас $є$ дійовою особою ("tâche de vivre") та спостерігачем за нею ("regarde" et "juge"), таке "doubling of the self" тематично, структурно i стилістично створює цілісний автентичний автобіографічний наратив, де виражається формування особистісної ідентичності та перебіг іiі кризи. У дискурсивному середовищі «Le vieillard et l'enfant» нами виділено психолінгвістичні маркери часу і простору, які становлять просторово-часовий компонент когнітивної складової особистісної ідентичності. Доведено, що трансформація ідентичності у сучасному світі може бути зрозуміла лише у термінах конструювання «Я» як рефлексивного проекту - здійсненні цілісного, біографічного оповідання, яке постійно коректується у поліваріативному контексті вибору. У такому випадку досягнення ідентичності розуміється як розробка траєкторії «Я», що стає чи не найважливішим життєвим завданням усуспільненого індивіда.

Ключові слова. особистісна ідентичність, дискурс, наратив, екзистенція, криза ідентичності, вербальні індикатори. 
Lukomska Svitlana Oleksiivna Phd, senior researcher of the Department of methodology and theory of psychology, G.S. Kostiuk Institute of Psychology of the National Academy of Pedagogical Sciences of Ukraine, Pankivska St., 2, Kyiv, 01033, tel.: (067) 836-08-24, e-mail: svitluk@ukr.net, https://orcid.org/0000-0002-0360-6484

\title{
LIFE NARRATIVES OF THE CHARACTERS OF G. ROY'S NOVEL "LA ROUTE D'ALTAMONT" AND THE MUSICAL ALBUM "LE VIEILLARD ET L'ENFANT", CREATED ON ITS BASIS
}

\begin{abstract}
The article analyzes the features of the life narratives of the characters of the novel by the Canadian writer G. Roy's "The Road to Past Altamont", in particular the second part of "Old Man and Child" and the eponymous music album, created in 2021 based on him. First published in French in 1966, the book's title is lifted from the last story "La Route d'Altamont" is a wonderful old-fashioned coming-of-agethemed 4-group of stories about a young francophone girl - Christine - growing up in lonely, windswept, pioneering Manitoba at the turn of the twentieth century. Christine is an autobiographical character, based on G. Roy, and Christine's memories and responses are, one must therefore speculate, Roy's. The four stories in this novel are connected, not only by the main character at different points in her life, but also thematically with the exploration of change, aging and how we relate to and understand our elders. The theoretical research question was what kinds of verbal indicators characterize personal identity following the example of G. Roy's novel and the musical album based on it. This empirical study based on the methods of discursive and narrative analysis of the novel "La Route d'Altamont" and the musical album "Le vieillard et l'enfant". It established that verbal markers of personal identity are time (prospective identity) and space (territorial identity). It is proved that personal identity in the novel and music album is presented in the form of an autobiographical narrative, stages of the crisis of personal identity in people of different ages, heredity of generations, options for solving existential problems that are relevant in crisis situations. Acquisition of personal identity is impossible without the choice of individual freedom, without finding one's place in a changing and unpredictable world. The instability of the world encourages freedom of choice, taking responsibility for their actions. G. Roy demonstrates the reflexivity of the characters of the novel through the image of her as "the author of the narrative" and as "his witness". Hence, one of the means of overcoming the identity crisis is reflexivity.
\end{abstract}

Keywords: narrative, discourse, personal identity, existence, authenticity, identity crisis.

Постановка проблеми. У сучасному суспільстві структура «Я» його індивідів набуває найбільшої когнітивної складності у порівнянні з будь-якою історичною епохою. Відповідно, питання про становлення ідентичності та можливі шляхи подолання ії кризи також набувають значної складності. Феномен ідентичності виникає в рамках глобальної проблематики існування самої людини, у цьому контексті особливого значення набуває осмислення поняття особистісної 
ідентичності не в світлі їі розрізнених аспектів, а базуючись на принципі компліментарності, тобто взаємодоповнюваності та мультиваріативного впливу на функціонування людини у динамічному мінливому світі. Не останню роль у цьому процесі відграє аналіз властивостей ідентичності персонажів літературних творів, зокрема нещодавно перекладених українською мовою.

Літературні твори постмодернізму характеризуються відкритими, неоднозначними завершеннями, які дають читачеві більше запитань, ніж відповідей. Крім того, популярне у 30-х роках $\mathrm{XX}$ століття протиставлення жіночого «Я» та усіх інших, у 60-х роках поступається місцем взаємодії жіночих і чоловічих - «материнських» і «батьківських» Я у амбівалентному перетині часу $\mathrm{i}$ місця розгортання події твору (J.-P. Boucher) [1].

Габріель Роу (1909-1983) - відома канадійська письменниця, громадський діяч, одна з головних фігур у франкомовній літературі Канади, іiі роман «Дорога до Альтамонту» (La Route d'Altamont, 1966) попри те, що містить чотири незалежні тексти, кожен 3 яких розповідає закінчену історію, не є збіркою оповідань, а - романом-сагою, жанром, який одночасно фрагментований i уніфікований, має гнучку структуру, яка базується на концепції життєвого шляху людини, а відповідно, дозволяє проаналізувати особистісну ідентичність його персонажів.

Аналіз останніх досліджень і публікацій. В оповіданнях Г. Роу історії героїв змінюються, розширюються та ускладнюються в процесі їх дорослішання, набуття життєвого досвіду і віддалення від материнської фігури (P. R. Gilbert) [4]. Наприклад, розгортання життєвого світу Крістін відбувається поступово: від гри з ляльками у себе вдома, де коло спілкування обмежено матір'ю (ключовий наратив «лялька»), мрії побачити щось нове, розширити коло своїх контактів (наратив «озеро»), знайомства 3 чоловічою фігурою, протилежною фігурі жіночій, але так само реалізуючій материнську функцію (наратив «рух») до відкриття абсолютно нового для себе світу, протилежного звичному, але не менш привабливого і захоплюючого - від манітобських прерій до пагорбів Вінніпегу (наратив «гора»). Попри логічність опису життєвого циклу, у творах Г. Роу висвітлено важливу психологічну проблему - втрату контролю над життєвими подіями - головну характеристику кризи особистісної ідентичності. Коли Крістін розуміє, що не все у власному житті може контролювати, зокрема такі природні життєві цикли як старіння та смерть, вона рефлексує свої відчуття і вербалізує їх, тим самим зменшуючи рівень тривоги за хід свого подальшого життя (L. Renée) [8].

Зазначимо, що роман «Дорога до Альтамонту» не є дитячим, охоплені ним теми психологічні та соціально-філософські. Дослідниця творчості Г. Роу Д. Фортьє спеціально для музичного альбому «Le vieillard et l'enfant» («Старий і дитина») адаптувала текст оповідання Г.Роу, чим уможливила його розуміння дітьми від 3 років, зберігши при цьому його базові проблеми, а саме: дитинство, родина, відкриття себе і світу в цілому, прагнення до самостійності і жага пригод [2].

Другу частину роману «La route d'Altamont» - «Le vieillard et l'enfant» було 
екранізовано однойменним фільмом (С. Grenier, C. Perron, 1985) та ілюстровано музичним альбомом (Д. Фортьє, Д. Лавуа, 2021). Зазначимо, що Г. Роу написала сценарій фільму до свого роману, три версії якого $є$ у фондах Національної бібліотеки в Оттаві, але про які режисери екранізації 1985 року не знали. Своєю екранізацією авторка хотіла зробити текст більш наочним, вона додала нові діалоги, щоб краще проілюструвати відносини між матір'ю i дочкою i дати можливість чітко простежити еволюцію відносин між людьми похилого віку, старим чоловіком i дитиною. Саме в сценарії Г. Роу акцентується на міжпоколінній взаємодії. По суті, сценарій є логічним продовженням оповідання. В екранізації C. Grenier, C. Perron характер персонажів змінився: дівчина показана більш пустотливою і сміливою, менш схильною до рефлексій, а старий - більш ностальгійним, зануреним у своє минуле, а не мудрим наставником, часто здається, що головною героїнею фільму є не Крістін, а іiі матір. У фільмі немає чітко окреслених наративів долі, послідовності життєвих циклів, діалоги максимально короткі, закадровий голос посилює розрив між малюнком і екрані та почутими словами [5]. Натомість музичний альбом «Le vieillard et l'enfant» (2021) складається із власне тексту Г. Роу, адаптованого D. Fortier, текстів пісень Ch. Vézina, музики D. Lavoie та ілюстрацій Rogé. У діалогах присутня комунікативна взаємодія між героями, тексти пісень і ілюстрації відображають ключові моменти оповідання Г. Роу - «рух», «подорож», «рівнину, «озеро», «міжпоколінну взаємодію», «роздуми»; автобіографічний наратив підкреслено музикою з використанням виключно акустичних інструментів. Д. Лавуа каже, що хотів відобразити простоту тексту засобами музики: «Ідея полягала в тому, щоб музикою проілюструвати казку у веселій, грайливій і світлій формі [...] Я хотів, щоб вона була досить акустичною, близькою до фольку» («L’idée était d'appuyer le conte d'une façon amusante, ludique et lumineuse [...] Je voulais garder ça assez acoustique, proche d'une musique folklorique»). На думку M. Larouche [5], якщо даний фільм можна вважати окремим твором, лише дотично пов'язаним із Г. Роу, то музичний альбом $\epsilon$ його візуалізацією та ауділізацією. Зазначимо, що символізація переживань, вираження ідентичності не словами, а символами, не нова для Г. Роу, так в оповіданні «Un jardin au bout du monde» емігрантка 3 України Марта, відповідаючи на питання ким вона є у Канаді, зазначає «les sentiments que l'on n'exprime jamais, qui vivent repliés dans les plus lointaines retraites de l'âme» («я ніколи не зможу виразити словами свої почуття, а тому зберігаю їх у найпотаємніших куточках своєї душі»), виражаючи себе невербально - у створенні квітника, що символізує їі особистість, реалізувати яку у неї немає можливості. Так і в альбомі «Le vieillard et l'enfant» більшість переживань героїв символічно виражені музикою, яка допомагає персонажам розкрити свою життєву історію, а слухачам - краще зрозуміти іiі.

Якщо розглядати роман «La Route d'Altamont» в цілому, то головна його героїня Крістін представлена у таких вікових відрізках як в ранньому дитинстві, в $6,8,11,14$ років і в молодості. Таким чином можна відстежити етапи їі вікового та психологічного дорослішання. В альбомі 2021 року вік дівчинки точно не вказано, ймовірно це 8-11 років, коли розвивається здатність до рефлексії, 
роздумів про себе, своє минуле і майбутнє, а також про ймовірну смерть (своїх рідних і власну).

Концепт особистісної ідентичності у тексті актуалізується насамперед в тому, що розповідь ведеться від імені Крістін, яка водночас є дійовою особою ("tâche de vivre") та спостерігачем за нею ("regarde" et "juge"), таке "doubling of the self" тематично, структурно і стилістично створює цілісний автентичний автобіографічний наратив, де виражається формування особистісної ідентичності та перебіг іiі кризи («... et il est vrai, parfois aussi, pour la communication. je suis devenue peu à peu une sorte de guetteuse des pensées et des êtres et cette passion pourtant sincère use l'insouciance qu'il faut pour vivre...», Route d'Altamont, p. 134) [9].

Метою статті $\epsilon$ аналіз особливостей життєвих наративів персонажів роману канадійської письменниці Г. Роу «Дорога до Альтамонту».

Виклад основного матеріалу. В емпіричному дослідженні використано методи дискурсивного і наративного аналізу роману «La Route d'Altamont» та музичного альбому «Le vieillard et l'enfant». Основним завдання дискурсивного аналізу є розуміння задуму текстів - набору ідей і уявлень, за допомогою якого автор пояснює і формує (використовуючи ілюстрації та музику) реальність. Наративний аналіз - це якісний метод дослідження, спрямований на інтерпретацію розповіді, що приділяє особливу увагу часовій послідовності, якої дотримуються оповідачі, говорячи про своє життя та оточуючі події. Для наративного аналізу важливо: наявність оповідача, глядача, читача чи слухача, послідовність подій, пережитих персонажем; а також ставлення оповідача до того, про що йде мова; відповідно, вербальні маркери особистісної ідентичності нами виділено базуючись на таких параметрах як оповідач (наратор), персонажі, час, події, простір, взаємовідносини між категоріями (дихотомії), інтертекстуальні зв'язки та культурні пресупозиції.

У дискурсивному середовищі «Le vieillard et l'enfant» нами виділено наступні психолінгвістичні маркери: час та простір, які становлять просторовочасовий компонент когнітивної складової особистісної ідентичності.

Важливим психологічним моментом, яскраво відображеним у «Le vieillard et l'enfant» $\epsilon$ цінність буття у ситуації «тут і тепер», по суті, зустріч минулого (старості) і майбутнього (дитинства) відбувається у теперішньому часі, саме тут співіснують два полюси життєвого циклу [6].

Припущення про наявність у структурі «Я» часових «модусів» $\epsilon$ традиційними для психологічних досліджень особистості. Починаючи 3 класичних робіт У. Джемса, в поняття «Я-концепції» закладалося не тільки актуальне уявлення про себе, а й те, як сам індивід оцінює можливості свого розвитку в майбутньому. Дослідження останнього десятиліття не тільки продовжили i розвинули іiі, а й зробили однією 3 центральних у всій проблематиці, пов'язаній 3 «Я». Передусім, це зумовлено введенням в активний науковий обіг поняття «можливого Я», яке відображає не тільки передбачуване майбутнє, але і нездійснене минуле. Воно не тотожне «ідеальному Я», заданому соціальними нормативами, оскільки містить негативні самохарактеристики, 
відрізняється й від «бажаного Я», безпосередньо визначеного мотиваціями людини, так як включає в себе рефлексію моментів мимовільності в саморозвитку. Сьогодні традиційна проблема «часу Я-концепції» в іï мотиваційному значенні все більш реалізується через дослідження так званої проспективної ідентичності - тих ідентифікаційних характеристик особистості, які віднесені до майбутнього [7]. Проспективна ідентичність розуміється як образ «Я-в-майбутньому», що включає в себе майбутню особистісну і соціальну ідентичність суб'єкта. По суті, це актуалізація одного 3 «можливих Я», взятого в соціальному оточенні Саме континуальність, представлена як єдність і цілісність буття людини в процесі перебігу часу, відображає темпоральну природу ідентичності. Описуваний критерій ідентичності забезпечується процесом перетворення будь-яких змін, що відбуваються 3 людиною і в людині, в безперервну, несуперечливу цілісність [10].

Протиставлення / об'єднання дитинства зі старістю є ключовим аспектом парадоксальної концепції часу, відображеної у романі Дорога до Альтамонту», а особливо в частині «Старий в дитина». Таким чином, протилежності, які не можуть ні узгодити, ні анулювати один одного, об'єднуються в парадоксі, в якому вони можуть співіснувати одночасно. Дійсно, через персонажів Крістін і СенІлера Г. Руа ілюструє парадоксальний хід часу, що протікає у вигляді пауз i ривків, в круговому русі, де протилежності об'єднуються - так дитинство i старість, два крайні полюси життя, зустрічаються і зливаються в одну точку в даний конкретний момент («temporalité et paradoxe», Fortier, 2002 [2]). Коли Крістін запитує мсьє Сен-Ілера, чим є далекі береги озера Вінніпег - його кінцем чи його початком, старий їй відповідає: « Кінець, початок? Ти задаєш дивне питання! Кінець, початок ... Що, якби це було одне й те саме! ... Може, все закінчується великим колом, в якому кінець і початок сходяться».

Справді, в той час як люди схильні до лінійного і невблаганного плину часу, здається, що діти і люди похилого віку належать іншому часу або навіть іноді виходять за його межі [3]. Те, що у них немає часу, не означає, що вони повинні поспішати, а скоріше те, що час не належить їм. Тонка межа, яка відокремлює життя від смерті або буття від небуття, коли час наближається до свого кінця або тільки починає свій відлік, слід абстрагуватися від нього і жити, хоча і на мить, в нерухомості, яка не належить вічності. Подорожуючи з мсьє Сен-Ілером, Крістін ставить собі питання, яке, на нашу думку, є ключовим у даному оповіданні: «Що значить прожити життя?» відповідаючи собі: «Це заново відкрити собі радість дитинства у той момент, коли стоїш на порозі смерті». Так стисла дитяча характеристика життя разюче схожа на визначення автобіографії або будь-якого твору, заснованого на автобіографічному натхненні, мета якого - за допомогою спогадів про дитинство і юність знайти і воскресити втрачений час.

В оповіданні «Le vieillard et l'enfant» декілька разів зустрічається вислів «заново відкритий час» (temps retrouvé), у тексті й цілого роману «La Route d'Altamont» він виявлений значно частіше, тобто $є$ важливим у міжпоколінній взаємодії бабусі Крістін, їі матері Евелін, власне Крістін і мсьє Сен-Ілера. Це не справжнє минуле, яке можна воскресити, пробудивши спогади, а ідилічне місце, 
яке належить зовсім іншому часу або, що ймовірніше, місце, розташоване поза часом i більше кероване уявою, ніж пам'яттю. У той час як традиційна автобіографія стосується власне «Я» і намагається відтворити індивідуальне i неповторне минуле, «La Route d'Altamont» веде мову від «Ми», що об'єднує кілька «Я», це по суті поліфонічне оповідання, в якому кілька голосів доповнюють один одного, щоб дійти згоди в множинній, але, тим не менш, єдиній перспективі особистісної ідентичності.

У працях Г. Роу географічний ландшафт символізує певний віковий етап життя людини, так рівнина $є$ метафорою дитинства, у романі «La route d'Altamont» прерії не просто географічне поняття, вони відображають через спогади відчуття приналежності до певної культурної спільноти, соціальну ідентичність Крістін. Ї̈̈ повернення до рівнини після подорожей до озера (дорослість) і пагорбів (старість), свідчить про примирення зі своїм минулими, яке проявляється в інтеріоризації життєвого простору, перетвореного в символічне місце, складність якого узгоджується 3 психологічним розвитком головної героїні.

Пейзаж, a точніше географічні протиставлення, наприклад, пагорби i рівнина, використовуються для характеристики головних героїв, таких як Крістін або ii мати в «La route d'Altamont». Подорож, здійснена двома жінками, до пагорбів Альтамонту, характеризується блуканнями, пригодами i пошуками самих себе. Пейзажі і персонажі зливаються, тому що Г.Роу абстрагується від реальної географії і зводить особистість тимчасовості: минулого, сьогодення i майбутнього, старості та юності, від'їзду і повернення. Потім проводиться ідентифікація кожної форми ландшафту. Дорога до Альтамонту дуже чітко ілюструє злиття персонажа i ландшафту за допомогою таких метафор, як «величезні бажання» («vastes désirs»), «загадкове небо» («ciel énigmatique»), «простору очікування» («еspaces en attente»), «міражу» («bien dans ses mirages»). B «La route d'Altamont» географічний ландшафт поступово трансформується в невизначений універсальний простір - сцену для розгортання життєвих історій.

Слід звернути увагу на наступні три символи, по-різному представлені в романі та музичному альбомі - «рівнина» (зона комфорту i дискомфорту одночасно, бажання змінити місце проживання і страх змін), «озеро» (щось нове, незвідане, пов'язане із пригодами) та «пагорби» (в дитячому альбомі не прописані, оскільки характеризують соціально-філософський аспект кінцевості життя, відкриття іншого світу «там за тим пагорбом»).

Життя Крістін та ii матері розгортається серед безкрайніх манітобських прерій, яскраво описаних у пісні Д. Лавуа «Jours de plaine» («Дні на рівнині»), примітно, що характеристика повсякденного життя мешканців Манітоби Г. Роу та Д. Лавуа (композитора альбому «Старий і дитина») практично співпадає («Дні рівнини, коли в хмарах можна побачити море, Вечори рівнини, коли відчуваєш себе єдиною людиною на землі»), а отже читач може чітко уявити, що відчувають герої роману, якими є їхні будні. Рівнина є символом очікування, нетерплячим прагненням отримати вісті здалеку. Саме на рівнині Крістін вперше замислюється над екзистенційними питаннями: що таке рух, що таке смерть, чи 
житиме людина в пам'яті інших після своєї смерті... і саме втома від рівнини спонукає дівчинку не пасивно чекати, а самостійно йти на зустріч новому. Так само як і Д. Лавуа, залишив Манітобу задля відкриття світу поза нею, написав знакову для себе пісню «J'ai quitté mon île» («Я покинув свій острів, Я покинув його спокійно, без пісень і сліз. Одним прекрасним ранком ви побачите вітрила мого корабля, що виходять у відкрите море»). У творчості Д. Лавуа виявляються концепти «острів» (île) (селище Данрі, де пройшло його дитинство» та «море» (mer) (як протилежне спекотній рівнині, але таке ж велике за розміром). Для Г. Роу подібними поняттями $є$ «вулиця» (rue) i «озеро» (lac). Якщо перше представлено більше у попередньому іiі романі «Rue Deschambault», де головною особою є все та ж дівчинка Крістін, то друге - символізується саме в оповіданні «Старий i дитина», а також яскраво проілюстроване музичним альбомом. У багатьох давніх культурах існувало уявлення про те, що озера - це священні місця, де живуть боги. Озеро символізує жіноче начало, очищення і зцілення, а також джерело життя в цілому. Крім того, вода завжди пов'язується 3 відносинами між глибоким і поверхневим, зовнішнім і внутрішнім. Для Крістін озеро стає символом інсайтів, відповідей на важливі для неї питання, зрештою, осмислення питань старіння, смерті, спогадів і життєвої історії. В музичному альбомі багато уваги приділено підготовці до подорожі на озеро, дорозі до нього i власне перебуванню на березі. Автори акцентували увагу на тому, що пошук відповідей на складні екзистенційні питання потребує тривалої підготовки, одночасно - можливості усамітнитися і поділитися своїми роздумами зі значущим Іншим, звідси, автобіографічний наратив неможливий в стані поспіху, він потребує часу для осмислення і відтворення.

Ще одним концептом-символом роману «Дорога до Альтамонту» i музичного альбому є власне «дорога» (route). Розвиток особистості, становлення iii ідентичності неможливо без поступового просування своїм життєвим шляхом, саме символ дороги уможливлює рефлексію власного досвіду на рівнині, озері i на пагорбі. Іншим концептом роману є «горизонт» (horizon). Це горизонт, який представляє майбутнє, набір можливостей, погано усвідомлених, часто утопічних, свого роду універсальний ідеальний стан, який ніколи не може бути досягнутий повністю однією людиною [3].

Щоб зазирнути за горизонт, Крістін вже 3 дитинства неодноразово намагається піднятися вище своєї точки опори, яка, кожного разу як би зміщується далі. Ця спроба змінити перспективу за допомогою висоти, необхідна для людей, що зважилися на глибоку психологічну зміну своєї особистості. Крістін, будучи дитиною, демонструє цю екзистенційну необхідність шляхом неодноразової підміни понять «attitude» (звичка) і «altitude» (висота над рівнем моря). Тут злиття простору-часу, рівнини і висоти стає дуже конкретним: самореалізація, пошук автентичного «Я» неможливі без зміни звичного на невідоме, саморозвитку і самовдосконалення.

Висновки. В результаті проведеного аналізу можна відзначити, що роман «Дорога до Альтамонту» $\epsilon$ автобіографічним наративом, тобто базується на життєвій історії, де акцентується, що неможливо бути автентичним, зі 
сформованою особистісною ідентичністю та вмінням ефективно проходити через ii кризи без прийняття власного життєвого досвіду, розуміння його ключових подій та їх емоційного перепрацювання. У будь-якому віці людина має свій життєвий наратив, усвідомлений, а значить i контрольований, звідси сформована особистісна ідентичність полягає не в останню чергу у збереженні контролю над своїм минулим. Набуття особистісної ідентичності неможливе без вибору індивідуальної свободи, без пошуку свого місця у мінливому i непередбачуваному світі. Рефлексивність головної героїні Г. Роу демонструє через зображення їі як «автора наративу» та як «його свідка». Стикаючись 3 проблемами, невизначеністю, стресом, особистість здатна «підніматися» над ситуацією, дивитися на себе та неї ніби зі сторони, конструюючи іiі модель, по суті, саме рефлексивність дозволяє людині оволодівати своїм життєвим шляхом, власним розвитком, освоїти суб'єктну позицію у соціальних стосунках. Отже, трансформація ідентичності у сучасному світі може бути зрозуміла лише у термінах конструювання «Я» як рефлексивного проекту - здійсненні цілісного, біографічного оповідання, яке постійно коректується у поліваріативному контексті вибору.

\section{Jimepamypa:}

1. Boucher J.-P. Recueil et voyage: La Route d'Altamont de Gabrielle Roy. Revue Littératures Université McGill. 1990. № 6. P. 39-57.

2. Fortier D. L'écriture comme paradoxe: étude de l'oeuvre de Gabrielle Roy. 2002. 324 p.

3. Franzen P. Margaret Laurence et Gabrielle Roy: un pays, deux mondes?. Cahiers francocanadiens de l'Ouest. 1996. № 8(2). P. 239-270.

4. Gilbert P. R. All Roads Pass Through Jubilee: Gabrielle Roy's La Route d'Altamont and Alice Munro's Lives of Girls and Women. Colby Quarterly. 1993. № 29(2). P. 136-148.

5. Larouche M. «Le vieillard et l'enfant»: le scénario de Gabrielle Roy. Cahiers francocanadiens de l'Ouest. 1997. № 9(1-2). P. 3-17.

6. Marcotte S. Correspondance, autobiographie et journal personnel chez Gabrielle Roy. Quebec Studies. 2001. № 31. P. 76-96.

7. Nezlek J. B., Schütz A., Sellin I. Self-presentational success in daily social interaction. Self and Identity. 2007. № 6(4). P. 361-379.

8. Renée L. Espace et asservissement dans La route d'Altamont de Gabrielle Roy. Cahiers franco-canadiens de l'Ouest. 1998. № 2. P. 271-280.

9. Roy G. La route d'Altamont. Mosaic: A Journal for the Interdisciplinary Study of Literature. 1970. № 3(3). P. 133-138.

10. Zinn M. E., Huntley E. D., Keating D. P. Resilience in adolescence: prospective self moderates the association of early life adversity with externalizing problems. Journal of adolescence. 2020. № 81. P. 61-72. https://doi.org/10.1016/j.adolescence.2020.04.004

\section{References:}

1. Boucher, J.-P. (1990) Recueil et voyage: La Route d'Altamont de Gabrielle Roy. Revue Littératures Université McGill, 6, 39-57.

2. Fortier, D. (2002). L'écriture comme paradoxe: étude de l'oeuvre de Gabrielle Roy

3. Franzen, P. (1996). Margaret Laurence et Gabrielle Roy: un pays, deux mondes?. Cahiers franco-canadiens de l'Ouest, 8(2), 239-270.

4. Gilbert, P. R. (1993). All Roads Pass Through Jubilee: Gabrielle Roy's La Route d'Altamont and Alice Munro's Lives of Girls and Women. Colby Quarterly, 29(2), 136-148. 
5. Larouche, M. (1997). «Le vieillard et l'enfant»: le scénario de Gabrielle Roy. Cahiers francocanadiens de l'Ouest, 9(1-2), 3-17.

6. Marcotte, S. (2001). Correspondance, autobiographie et journal personnel chez Gabrielle Roy. Quebec Studies, 31, 76-96.

7. Nezlek, J. B., Schütz, A., \& Sellin, I. (2007). Self-presentational success in daily social interaction. Self and Identity, 6(4), 361-379.

8. Renée, L. (1998) Espace et asservissement dans La route d'Altamont de Gabrielle Roy. Cahiers franco-canadiens de l'Ouest, 2, 271-280.

9. Roy, G. (1970). La route d'Altamont. Mosaic: A Journal for the Interdisciplinary Study of Literature, 3(3), 133-138.

10. Zinn, M. E., Huntley, E. D., \& Keating, D. P. (2020). Resilience in adolescence: prospective self moderates the association of early life adversity with externalizing problems. Journal of adolescence, 81, 61-72. https://doi.org/10.1016/j.adolescence.2020.04.004 